\title{
Hematologic Changes and Hemoglobin Analysis in $\beta$ Thalassemia Heterozygotes during the First Year of Life
}

\author{
W. G. WOOD, ${ }^{(33)}$ D. J. WEATHERALL, G. H. HART, M. BENNETT, AND G. W. MARSH \\ MRC Molecular Haematology Unit and Nuffield Department of Clinical Medicine, University of Oxford, John \\ Radcliffe Hospital, Oxford, England, [W. G. W. and D. J. W.] and Department of Haematology, North \\ Middlesex Hospital, Edmonton, London, England, [G. H. H., M. B. and G. W. M.]
}

\section{Summary}

We have studied the hematology and hemoglobin patterns of normal and heterozygous $\beta$ thalassemia infants in serial samples obtained during the first year of life. The hemoglobin level, mean cell volume and mean cell hemoglobin were significantly lower in the $\beta$ thalassemia traits by the age of 3 months and this difference was maintained throughout the first year. $\mathrm{Hb} \mathrm{A}_{2}$ levels were significantly higher in the $\beta$ thalassemia group but increased in both groups throughout the first year. $\mathrm{Hb} F$ levels were also higher in heterozygotes for $\beta$ thalassemia at all ages, showing a delay in the postnatal decline.

\section{Speculation}

The low mean cell hemoglobin, elevated $\mathrm{Hb} F$ level and increased susceptibility to oxidant damage which characterise the red cells of heterozygous $\beta$ thalassemia infants may combine to protect these infants against $P$. falciparum malaria.

Heterozygous $\beta$ thalassemia is usually characterised in adults by hypochromic, microcytic red cells, an increased proportion of $\mathrm{Hb} \mathrm{A}_{2}$ and normal or slightly elevated amounts of $\mathrm{Hb} \mathrm{F}\left(\alpha_{2} \gamma_{2}\right)$, as a result of the deficit in $\beta$ chain production (30). This deficit is also expressed in fetal life (allowing antenatal diagnosis of the disease); however, the proportion of $\beta$ chain synthesis is so low it has little effect on the red cells, and these characteristic changes only become apparent when $\mathrm{Hb} \mathrm{A}\left(\alpha_{2} \beta_{2}\right)$ production replaces $\mathrm{Hb}$ $F$ in the postnatal period. The changes in the hematologic parameters and hemoglobin pattern during the first year of life in $\beta$ thalassemia heterozygotes have not been well characterised. Further examination of these patterns may be important for several reasons. First, it is not yet clear at which age the diagnosis of $\beta$ thalassemia trait can be established for certain. Furthermore, it may be important to be able to distinguish between $\beta$ thalassemia trait and the milder forms of $\beta$ thalassemia intermedia during the first year of life. In addition, there is some evidence that the switch from $\mathrm{Hb} \mathrm{F}$ to $\mathrm{Hb} \mathrm{A}$ production may be delayed in $\beta$ thalassemia heterozygotes $(2,4)$. It has been suggested that increased $\mathrm{Hb} F$ levels in early childhood may be the mechanism by which the $\beta$ thalassemia gene confers protection gainst $P$. falciparum malaria $(1,16,23)$.

We have studied the offspring of heterozygous $\beta$ thalassemia women and compared the hematologic changes and differences in the hemoglobin pattern between the normal and $\beta$ thalassemia trait children during the first year of life.

\section{MATERIALS AND METHODS}

Patient selection. A screening programme for women attending the antenatal clinic of the North Middlesex Hospital identified pregnant women who were heterozygotes for $\beta$ thalassemia. Those women whose husbands were shown not to carry the $\beta$ thalassemia gene were approached at delivery for permission to carry out blood sampling of their offspring at 3 monthly intervals after birth. In this way data on heterozygous $\beta$ thalassemia children and an equal number of normal children could be obtained in an unbiassed manner.

The majority of these women were of Cypriot origin. In addition one patient each of Italian, Indian, Chinese and West Indian origin were included in the study.

Sampling. Cord blood and follow-up samples at 3 and 6 months were obtained from 22 infants, who subsequently were shown by their $\mathrm{Hb} \mathrm{\textrm {A } _ { 2 }}$ levels to break down into $13 \beta$ thalassemia heterozygotes and 9 normals. Because some cases declined to complete the study, sample numbers in each group were reduced to 12 and 5 respectively at 9 months and 9 and 5 respectively at 12 months. Blood samples were obtained as closely as possible to 3,6,9 and 12 months after birth; the majority of samples falling within $2 \mathrm{wk}$ of the exact date, exept in a few exceptional cases which were within 4 wk.

Hematologic studies and hemoglobin analysis. A $2 \mathrm{ml}$ venepuncture, or occasionally a heel prick sample, was taken into EDTA. Hematologic parameters were measured on a Coulter model electronic cell counter. Hemoglobin analysis was carried out by starch gel electrophoresis in a tris-EDTA-borate buffer $\mathrm{pH} 8.6$ (30). $\mathrm{Hb}$ $\mathrm{A}_{2}$ was quantitated after electrophoresis and elution from cellulose acetate membranes (30) while $\mathrm{Hb} F$ was measured by an alkali denaturation technique (25).

\section{RESULTS}

The mean, S.D. and range of values obtained for the hemoglobin level, $\mathrm{MCV}, \mathrm{MCH}, \mathrm{Hb} \mathrm{F}$ and $\mathrm{Hb} \mathrm{A}_{2}$ levels in the two groups are shown in Tables 1 and 2 for the various time points examined and these changes are illustrated in Figures $1-3$. In addition, the absolute amounts of $\mathrm{Hb} \mathrm{F}$ (in $\mathrm{g} / \mathrm{dl}$ ) were calculated from the hemoglobin level and the $\% \mathrm{Hb} \mathrm{F}$ and the mean amount of $\mathrm{Hb} \mathrm{F} /$ cell (ignoring the intercellular distribution) was calculated from the $\mathrm{MCH}$ and $\% \mathrm{Hb} \mathrm{F}$.

Hemoglobin levels. The hemoglobin levels in the $\beta$ thalassemia heterozygotes were consistently $1-2 \mathrm{~g} / \mathrm{dl}$ lower than in the normal infants throughout the first year of life, including the cord blood samples.

$M C V$ and $M C H$. At birth, there was no significant difference in the mean cell volume $(\mathrm{MCV})$ and mean cell hemoglobin $(\mathrm{MCH})$ between the two groups of offspring but at all subsequent stages values were significantly lower in the $\beta$ thalassemia heterozygotes. In the normal infants, the values declined to subnormal adult levels until 6 months of age and then remained unchanged up to 1 year. A similar pattern was observed in the $\beta$ thalassemia heterozygotes, the level of $\sim 19 \mathrm{pg}$ from $6-12$ months of age being 
Table 1. Hematologic changes and hemoglobin analysis in a group of normal children during the first year of life

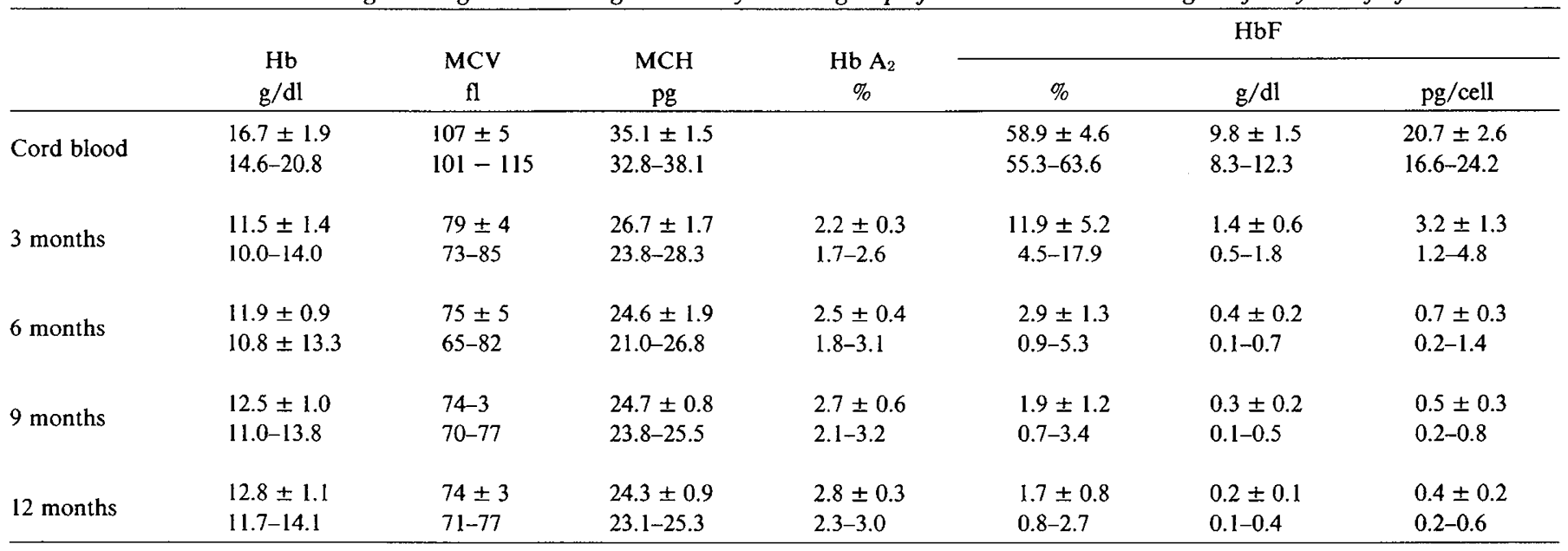

Table 2. Hematologic changes and hemoglobin analysis in a group of $\beta$ thalassemia heterozygotes during the first year of life.

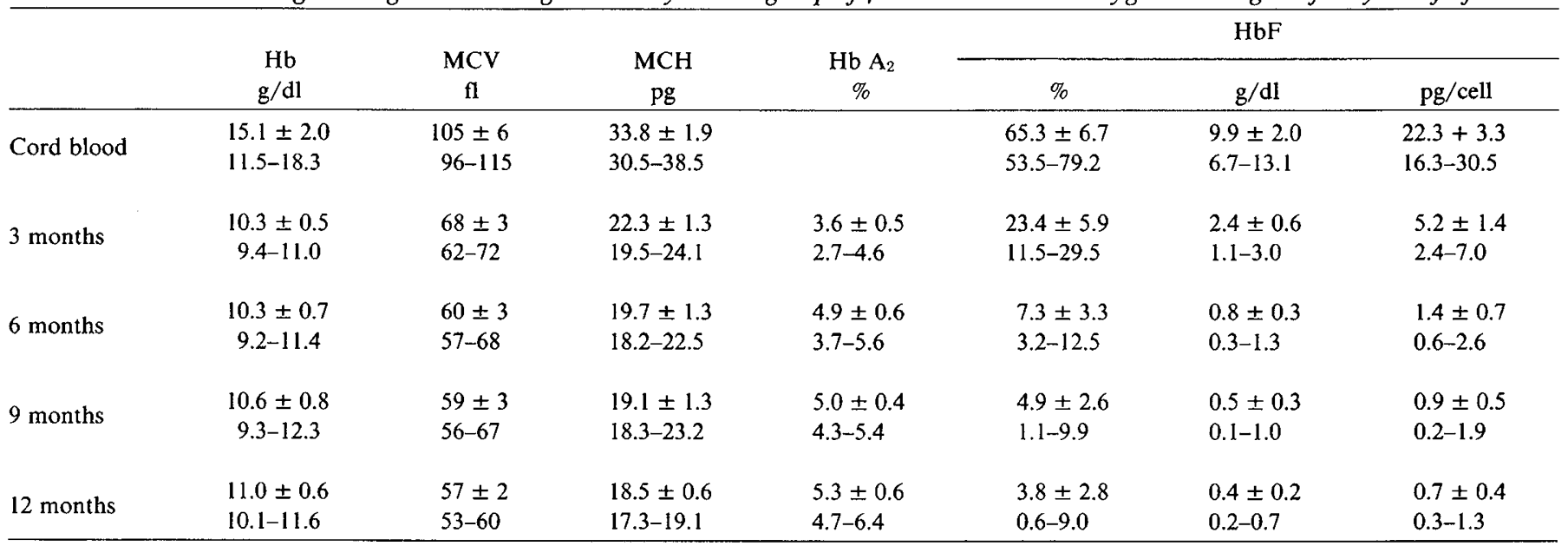

lower than the mean level of $21.8 \pm 2.1$ pg observed in 348 Cypriot adults with $\beta$ thalassemia trait (Marsh et al.; in preparation).

$\mathrm{Hb} \mathrm{A} \mathrm{A}_{2}$ level. The $\mathrm{Hb} \mathrm{\textrm {A } _ { 2 }}$ levels increased in both groups throughout the first year of life but with the major part of the increase occuring in the first 6 months. At all ages the levels in the $\beta$ thalassemia heterozygotes were significantly higher than in the normal infants, having reached or surpassed the upper limit of normal by 3 months.

$H b$ F level. $\mathrm{Hb} F$ levels in the cord bloods of the two groups were not significantly different but since the alkali denaturation procedure is not very accurate at such high levels of $\mathrm{Hb} F$ these results have little significance. At all subsequent stages, the mean $\%$ of $\mathrm{Hb} F$ was significantly higher in the $\beta$ thalassemia heterozygotes, but with some overlap in individual values between the two groups. When converted to $\mathrm{g} \mathrm{Hb} \mathrm{F} / \mathrm{dl}$ or $\mathrm{pg} \mathrm{Hb} \mathrm{F/cell,} \mathrm{these}$ differences, though slightly diminished, were retained.

\section{DISCUSSION}

This study has demonstrated that significant differences in red cell indices and hemoglobin pattern can be detected in $\beta$ thalassemia heterozygotes as early as 3 months after birth. Whereas for each parameter examined, there was some overlap between the normal and $\beta$ thalassemia trait groups, a comparison of the MCV, $\mathrm{MCH}, \mathrm{Hb} \mathrm{\textrm {A } _ { 2 }}$ and $\mathrm{Hb} \mathrm{F}$ levels would allow differentiation between the two in the great majority of cases. The design of the study, i.e., prospective selection and serial sampling, limited the number of individuals examined but avoided the problems of random sampling of infants attending hospital during the first year of life.
The decline in $\mathrm{Hb}$ level and in the MCV and $\mathrm{MCH}$ in the normal group of infants was similar to that which has been previously documented $(8,15,19,27)$. In the $\beta$ thalassemia heterozygotes, the values were lower but the overall pattern was the same as for the normal group. It is not clear why the MCV and $\mathrm{MCH}$ are lower at 6 months to 1 year of age than they are in adult life but this could be related to iron status or to changes in the pattern of erythropoiesis.

In accord with previous studies $(10,17,28)$, our results demonstrate that the major increase in $\mathrm{Hb} \mathrm{A}_{2}$ levels occurs in the first 6 months of life. Among the $\beta$ thalassemia heterozygotes (the majority of whom, being Cypriots, will have $\beta^{+}$thalassemia), the $\mathrm{Hb} \mathrm{A_{2 }}$ levels were significantly different from the normal infants even at 3 months of age. The differences were greater than those observed $(28)$ in a cross-sectional study of Negro infants with $\beta^{+}$ thalassemia trait.

Significant differences were also observed in the $\mathrm{Hb} \mathrm{F}$ levels between the groups, the $\beta$ thalassemia heterozygotes showing a markedly delayed decline in $\mathrm{Hb}$ F. Similar data have recently been presented in a cross-sectional study of young children in Greece (20). The mechanism by which this delay is brought about could be of importance for our understanding of the normal switch from $\mathrm{Hb} F$ to $\mathrm{Hb}$ A production and three possible mechanisms can be conisdered. First, since the $\gamma$ and $\beta$ chain genes are closely linked members of the $\beta$-like family of globin genes, the increased $\mathrm{Hb} \mathrm{F}$ production in $\beta$ thalassemia heterozygotes could be a direct result of the $\beta$ thalassemia defect, acting at the transcriptional or posttranscriptional level. There is no evidence to support this suggestion because $\beta^{+}$thalassemia is not due to a gross structural 

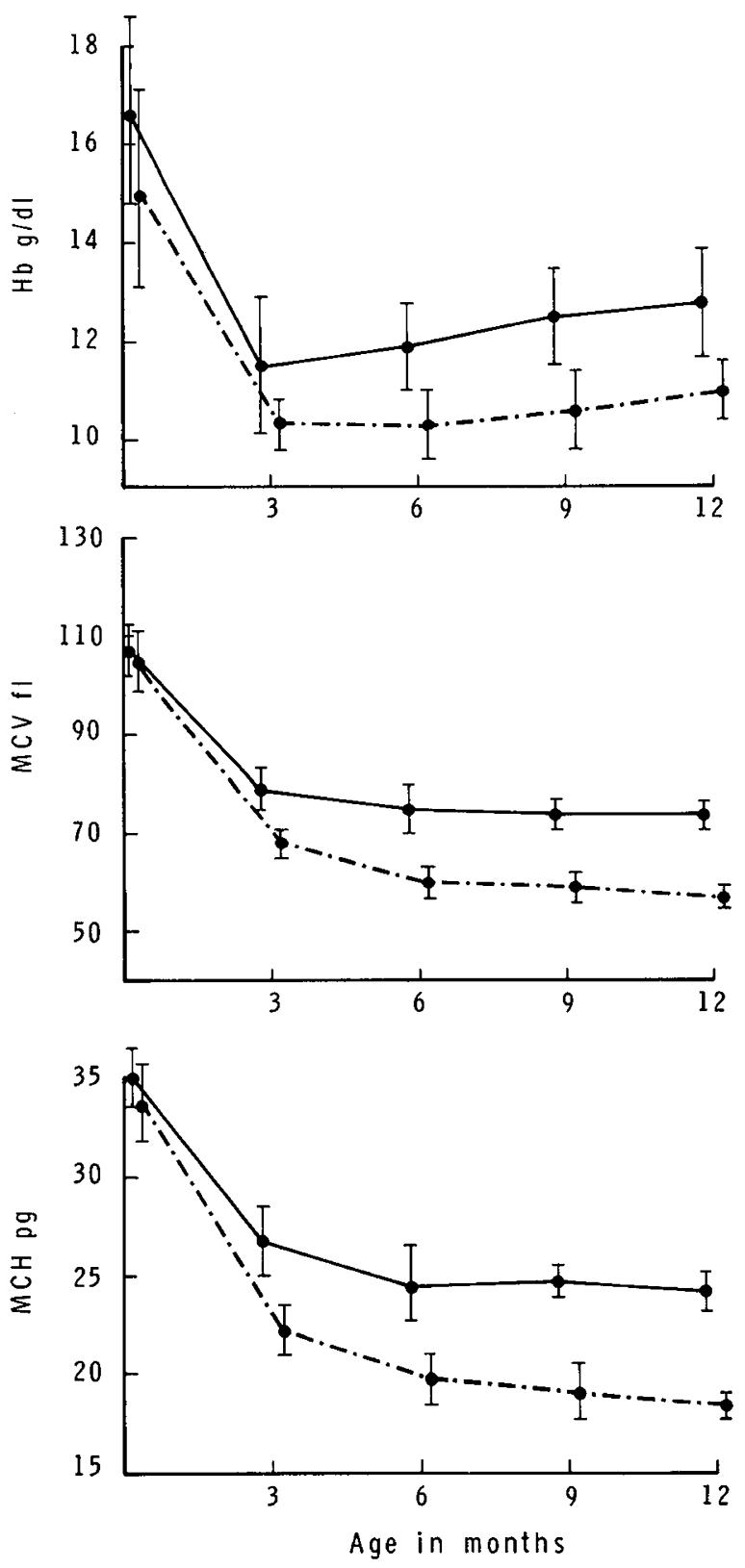

Fig. 1. Hemoglobin level, MCV and $\mathrm{MCH}$ in normal (-) and heterozygous $\beta$ thalassemia (----) infants during the first year of life (Mean \pm l S.D.).

rearrangement of the DNA (11) but, at least in some cases, results from a defect in RNA processing $(14,18)$. Thus a direct effect of the $\beta$ thalassemia defect on $\gamma$ gene transcription seems most unlikely; nor is there any evidence to support an effect on the posttranscriptional regulation of $\gamma$ chain production.

Second, an alteration in the kinetics of erythropoiesis in heterozygous $\beta$ thalassemia infants might result in increased $\mathrm{Hb} \mathrm{F}$ production because it is known that acquired conditions associated with acute erythroid expansion result in increased $\mathrm{Hb} F$ production $(3,9,22)$. This explanation also seems unlikely, unless either the effect of globin chain imbalance on red cell production is more severe in early life than later (see below) or the tendency toward elevated $\mathrm{Hb} \mathrm{F}$ production with increased erythropoiesis is greater in young infants. Neither of these possibilities can be dismissed.

The third alternative is that the increased levels of $\mathrm{Hb} F$ in $\beta$ thalassemia infants are a result of selective survival of those cells containing most $\mathrm{Hb} \mathrm{F}$. This mechanism may well be responsible for much of the increased $\mathrm{Hb} \mathrm{F}$ in $\beta$ thalassemia homozygotes (31) since those cells with most $\gamma$ chain production will have the



Fig. 2. Percentage $\mathrm{Hb} \mathrm{A}_{2}$ in normal (- $(-)$ and heterozygous $\beta$ thalassemia (----) infants during the first year of life (Mean \pm 1 S.D.).

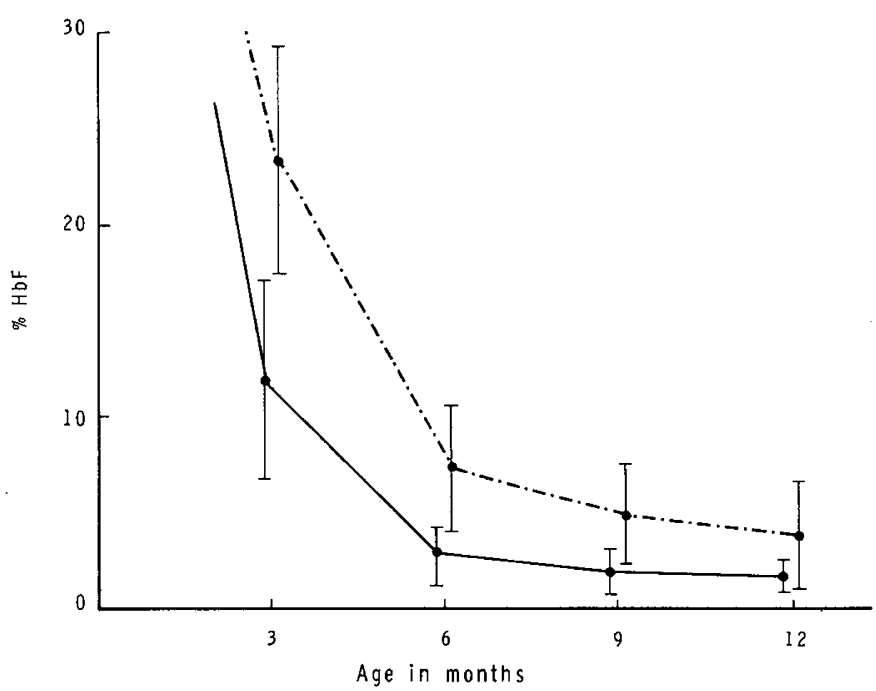

Fig. 3. Percentage $\mathrm{Hb} F$ in normal (- - and heterozygous $\beta$ thalassemia (----) infants during the first year of life (Mean \pm 1 S.D.).

least chain imbalance. In heterozygotes, it is generally considered that the cell is capable of handling the degree of $\alpha$ chain excess which occurs, probably by proteolysis. On the other hand, recent measurements of ineffective erythropoiesis in $\beta$ thalassemia heterozygotes have pointed to a much greater degree of intramedullary red cell destruction than was previously believed to occur (7). Furthermore, the red cells in newborns and young infants are much more susceptible to oxidant damage than adult red cells (29). One consequence of excess globin chains is the production of superoxides and peroxides $(6,26)$. The increased susceptibility of red cells in young infants to damage by excess globin chains is also suggested by observations in newborns, heterozygous for $\gamma$ $-\beta$ thalassemia, who present with a severe hemolytic anemia but which disappears as the child gets older. This occurs despite the fact that the degree of chain imbalance remains unchanged (13, 21 ). Thus, in the young infant, increased $\mathrm{Hb} \mathrm{F}$ production may well have a greater benefical effect and hence there may be a more pronounced selective survival of cells containing $\mathrm{Hb} \mathrm{F}$.

With the data presented here and that recently reported $(5,12)$ on the hematologic changes in $\beta$ thalassemia heterozygotes between the ages of 1 and 18 years, we now have a fairly complete picture of these changes during early childhood. Probably it is during this period that the $\beta$ thalassemia gene confers its protection against $P$. falciparum malaria. It has been demonstrated in vitro that the presence of $\mathrm{Hb} \mathrm{F}$ within a red cell retards the development 
of $P$. falciparum $(23,24)$. It is not clear how important this effect might be in vivo, nor what level of intracellular $\mathrm{Hb} \mathrm{F}$ is necessary to produce such as effect. The levels of $\mathrm{Hb} \mathrm{F}$ in the $\beta$ thalassemia trait infants, whilst significantly higher than normals, are still less than $5 \%$ by 9 months of age. This may provide some increased protection for a larger proportion of the cells but it seems unlikely that this is the sole reason which maintains the balanced polymorphism. However the combination of increased $\mathrm{Hb} \mathrm{F}$, a very low intracellular haemoglobin content and an increased susceptibility of the cell to oxidant damage may retard parasite growth sufficiently to give $\beta$ thalassemia heterozygotes a selective advantage over normal infants in early childhood.

\section{REFERENCES AND NOTES}

1. Allison, A. C.: Protection afforded by sickle cell trait against subtertian malarial infection. Br. Med. J., l: 290 (1954).

2. Alter, B. P.: Fetal erythropoiesis in stress hematopoiesis. Exp. Hematol., 7: 200 (1979).

3. Alter, B. P.: The ${ }^{\mathrm{G}} \gamma^{\mathrm{A}} \gamma$ composition of fetal hemoglobin in fetuses and newborns. Blood, 54: 1158 (1979).

4. Beaven, G. H., Ellis, M. J., and White, J. C.: Studies on human foetal haemoglobin. III. The hereditary haemoglobinopathies and thalassaemias. Br. J. Hematol., 7: 169 (1961).

5. Berman, B. W., Ritchie, A. K., Jekel, J. F., Schwartz, A. D., Guiliotis, D. K., and Pearson. H. A.: Hematology of $\beta$ thalassemia trait-age related developmental aspects and intrafamilial correlations. J. Pediatr., 97: 901 (1980).

6. Brunori, M., Falcioni, G., Fiorreti, E., Giardina, B., and Rotilio, J.: Formation of superoxide in the autoxidation of the isolated $\alpha$ and $\beta$ chains of human hemoglobin and its involvement in hemichrome precipitation. Eur. J. Biochem., 53: 99 (1975).

7. Cazzola, M., Alessandrino, P., Barosi, G., Marandi, S., and Stefanelli, M.: Quantitative evaluation of the mechanism of the anemia in heterozygous $\beta$ thalassemia. Scand. J. Hematol., 23: 107 (1979).

8. Dallman, P. R. and Siimes, M. A.: Percentile curves for hemoglobin and red cell volume in infancy and childhood. J. Pediatr., 94: 26 (1979).

9. Dover, G. J., Boyer, S. H., and Zinkham, W. H.: Production of erythrocytes that contain fetal hemoglobin in anemia. Transient in vivo changes. J. Clin. Invest., 62: 173 (1979).

10. Erdem, S. and Aksoy, M.: The increase of hemoglobin $A_{2}$ to its adult level. Israel J. Med. Sci. 5: 427 (1969).

11. Flavell, R. A., Bernards, T., Kooter, J. M., DeBoer, E., Little, P. F. R., Annison, G., and Williamson, R.: The structure of the human $\beta$ globin gene in $\beta$ thalassemia. Nucl. Acids. Res., 6: 2749 (1979).

12. Galanello, R., De Virgiliis, S., Addis, M., Paglietti, E., Ruggeri, R., and Cao, A. Hematological characteristics of the $\beta^{\prime \prime}$ thalassemia trait in Sardinian children. J. Clin. Pathol., 33: 946 (1980).

13. Kan, Y. W., Forget, B. G., and Nathan, D. G.: Gamma-beta thalassemia: a cause of hemolytic disease of the newborn. N. Engl. J. Med., 286: 129 (1972).

14. Kantor, J. A., Turner, P. H., and Nienhuis, A. W.: Beta thalassemia: Mutations which affect processing of the $\beta$-globin mRNA precursor. Cell, 21: 149 (1980),

15. Koerper, M. A., Mentzer, W. C., Brecher, G., and Dallman, P. R.: Developmental changes in red blood cell volume: implications in screening infants and children for iron deficiency and thalassemia trait. J. Pediatr., 89: 580 (1976).

16. Lehmann, H.: Sickle-cell anaemia. Br. Med. J., 2: 1217 (1953).

17. Masera, G.: Diagnosis di eterozigotismo per la $\beta$ talassemia net primoanno di vita. Minerva Pediatr., 20: 686 (1968).

18. Maquat, L. E., Kinniburgh, A. J., Beach, L. R., Honig, G. R., Lazerson, J Ershler, W. B., and Ross, J.: Processing of human $\beta$-globin mRNA precursor to mRNA is defective in three patients with $\beta^{+}$-thalassemia. Proc. Natl. Acad. Sci. USA, 77: 4287 (1980).

19. Matoth, Y., Zaizov, R., and Varsano, I.: Postnatal changes in some red cell parameters. Acta Pediatr. Scand., 60: 317 (1971).

20. Metaxotou-Mavromati, A., Antonopoulou, E., Laskari, S., Ladis, V., and Kattamis, $\mathrm{C} .: \mathrm{Hb} F$ in normal and heterozygote for $\beta$ thalassemia infants. XVI International Congress of Pediatrics. Abstracts p. H26, (1980)

21. Oort, M., Heerspink, W., Roos, D., Flavell, R. A., and Bernini, L. F.: Hemolytic disease of the newborn and chronic anaemia induced by gamma-delta-betathalassaemia in a Dutch family. Br. J. Haematol. (in press).

22. Papayannopoulou, Th., Vichinsky, E., and Stamatoyannopoulos, G.: Fetal Hb production during acute erythroid expansion. Br. J. Haematol., 44: 535 (1980).

23. Pasvol, G., Weatherall, D. J., and Wilson, R. J. M.: Effect of foetal haemoglobin on susceptibility of red cells to Plasmodium falciparum. Nature, 270: 171 (1977)

24. Pasvol, G., Weatherall, D. J., Wilson, R. J. M., Smith, D. H., and Gilles, H. M. Fetal haemoglobin and malaria. Lancet, $1: 1269$ (1976).

25. Pembrey, M. E., McWade, P., and Weatherall, D. J.: Reliable routine estimation of small amounts of foetal haemoglobin by alkali denaturation. J. Clin. Path., 25: 738 (1972).

26. Rachmilewitz, E. A., Lubin, B. H., and Shohet, S. B.: Lipid membrane peroxidation in $\beta$ thalassemia major. Blood, 47: 495 (1976).

27. Saarinen, U. A. and Siimes, M. A.: Developmental changes in red blood cell counts and indices of infants after exclusion of iron deficiency by laboratory criteria and continuous iron supplementation. J. Pediatr., 92: 412 (1978)

28. Serjeant, B. E., Mason, K. P., and Serjeant, G. R.: The development of haemoglobin $A_{2}$ in normal Negro infants and in sickle cell disease. Br. J. Haemat. 39. 259 (1978)

29. Stocks, J., Offerman, E. L., Modell, C. B., and Dormandy, T. L.: The susceptibility to autoxidation of human red cell lipids in health and disease. Br. J. Haemat. 23: 713 (1972)

30. Weatherall, D. J. and Clegg, J. B.: The thalassaemia syndromes. 3rd edition, Blackwell Scientific Publications. Oxford. (1981).

31. Weatherall, D. J., Clegg, J. B., and Wood, W. G.: A model for the persistence or reactivation of fetal haemoglobin production. Lancet, 2: 660 (1976).

32. The authors would like to thank the obstetricians (Mr JC Brace, Mr RV Clements and Miss MJ Witt) and the paediatricians (Dr SR Lewis and Dr MA Rossiter) at the North Middlesex Hospital for permission to study the patients under their care. We also thank Miss $J$. Sharpe for her excellent technical assistance.

33. Requests for reprints should be addressed to: Dr. W. G. Wood, MRC Molecular Haematology Unit and Nuffield Department of Clinical Medicine, University of Oxford, John Radcliffe Hospital, Oxford, England.

34. Received for publication May 18, 1981.

35. Accepted for publication August 5, 1981. 